\title{
Co-Evolution of the Willow (Genus Salix) and Humankind with Particular Emphasis on Estuarine and Delta Systems
}

\author{
Heike Markus Michalczyk* \\ Royal Netherlands Institute for Sea Research, Department Estuarine and Delta Systems, The Netherlands
}

Submission: July 27, 2018; Published: August 08, 2018

*Corresponding author: Heike Markus Michalczyk, Royal Netherlands Institute for Sea Research, Department Estuarine and Delta Systems, Korringaweg 7, NT Yerseke, The Netherlands, Tel: 00494071215 10; Email: markus-michalczyk@naturundumwelt.info

Keywords: Genus Salix; Estuarine; Human Kind; Delta Systems; Salicaceae; Sedimentation; Erosion; Fragmentation; Bulrush; Shrubs; Environment; Hybridization; Floodplains; Cultivation; Twigs; Euphrates

\section{Introduction}

The willow (genus Salix) thrived in the floodplain environment since the upper cretaceous period, e.g. fruiting Salix catkins were found in the Pipe Creek Valley, Dakota (Figure 1). The life history of Salicaceae is closely related to riverine habitats. Therefore, characteristic traits have evolved. Efficient seed production is followed by establishment on exposed riverine sediments and fast growth. High bending capacity and breaking resistance make Salix shrubs and trees resilient to river currents and waves [1], erosion and sedimentation processes [2]. Moreover, plant parts resprout vigorously after fragmentation by physical disturbance and flooding [3].

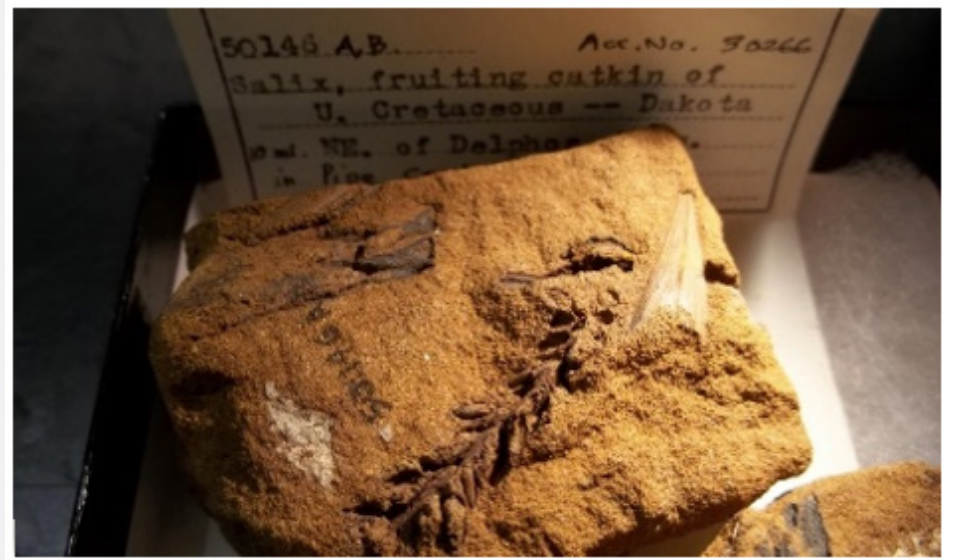

Figure 1: Salix sketch, fruiting catkins with leaf fragments recorded in the National Collection of the National Museum of Natural History, Washington DC, USA.

Ancient civilisations developed settlements along major flows. Willows naturally occurring in floodplains were used for dwellings along the Euphrates more than 10.000 years ago and for construction, tool handles, hoes and ploughs during the dynasty of Ur in Mesopotamia [4]. Willows provided flexible twigs and branches for furniture, fences for shelter, and fish traps. Willow baskets for food, supply and for storage may have been among the first articles manufactured by human hunter-gatherer communities [5]. The Food and Agriculture Organization of the United Nations FAO [4] highlights willows as "Trees for Society and the Environment" serving humankind since the dawn of history.

\section{Global Distribution}

Salix is a globally distributed species rich genus that can be divided into two ecological groups, (i) non-alluvial species of forest, rocks, wetlands with stagnant water and prostrate shrubs of tundra and alpine habitats, and (ii) narrow-leaved alluvial tree and large shrub species adapted to floodplains used for their flexible shoots [6]. The largest tree Salix species belong to the widely distributed and cultivated willows of the floodplain environment (Figure 2). The white willow (Salix alba L.) forms softwood floodplain forests throughout Europe up to North Africa, Asia Minor and western Asia, and is worldwide 


\section{Global Journal of Archaeology \& Anthropology}

planted near human habitations and on riverbanks. The Black willow (Salix nigra M.) forms extended forest stands along large rivers in North America, whereas $S$. humboldtiana W. is the only Salix species native to South American floodplains [7]. Salix phylogeny is complex due to frequent interspecific hybridization. Hybridization accompanied by polyploidy likely played a major role in modern Salix species evolution in genetically variable populations in disturbed floodplains and in cultivation [1].

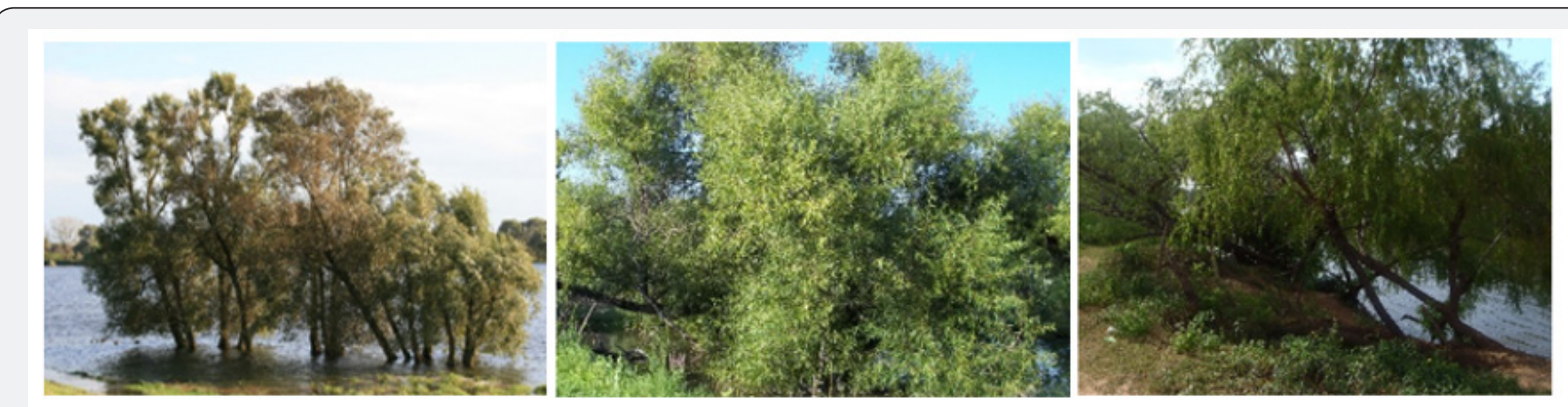

Figure 2: Widely distributed floodplain willow tree species.

(a) S. alba, Elbe, Germany.

(b) S. nigra, Potomac, United States of America.

(c) S. humboldtiana, Aquidauna, Brazil, each of which is intensively utilized and cultivated by humans.

\section{Estuarine and Delta Systems}

In South America, S. humboldtiana settles on non-tidal sandy deposits up to where the lower Parana Delta propagates in the Rio de la Plata estuary. Estuarine islands have been subjected to land use change since decades and today willow-plantations cover extended tidal freshwater wetlands [8]. Tidal freshwater wetlands were occupied by humans since they developed in coastal plain estuaries during the last 6.000 years. Ports were established because these sheltered locations were the most inland point in the estuary that could be reached by ships and where river discharge prevents salt water intrusion, but flat topography allows tides to determine the geomorphology and hydrodynamics [9].

Along the US Atlantic coast, downstream located oligohaline marshes were transferred into tidal freshwater forested wetlands due to colonial land clearance $300-500$ years ago shifting sediment into tidal wetlands, resulting in increased accretion. More recently, tidal freshwater forest declines due to tidal inundation and increasing salinity from sea level rise [10], e.g. in the Mississippi Delta where the Black willow forms extended forest stands. Similarly, S. humboldtiana may be substituted by some ten-thousand hectares of tidal forest plantations consisting of hybrid-willows (S. alba and $S$. babylonica L. (syn. S. matsudana Koidzumi) genotypes exist in the Rio de la Plata Delta. Salix babylonica grows originally in sandy river valley depression in arid-semiarid regions of China with pendulous branches. The weeping willow is one of the most widely used tree in horticultural and environmental application [7] eventually due to adaptation to changing water levels.

\section{North Sea Region}

In the North Sea Region, vast tidal freshwater wetlands containing willows still occur along the Scheldt, Belgium, the Weser and the Elbe, Germany, in De Biesbosch and along the
Oude Maas in the Netherlands [11]. Most European TFW were utilized by humans for similar reasons as in North America due to the availability of water, nutrient-rich soils for agriculture and the abundance of fish, shellfish, mammals, and plants for food and shelter. However, humans may have also been negatively impacted by flooding and mosquito-borne diseases [9]. Willows extract large quantities of water due to high evapotranspiration rates (phreatophyte-type of vegetation), and from historical references it is reported that willow plantations in malaria affected areas were the most effective for drying up the earth and thus sheltered human settlements [12]. The pulverized bark of Salix alba is even said "its having the properties of the Peruvian bark" and similar effects on "the agues" [13]. The "Marsh-Fever" occurred in brackish coastal and estuarine areas in North-West Europe connected to the occupational history. These areas were exploited by Ertebolle and Swifterbant people since the 5 th millennium BC. Subsequent sedentary communities utilized fertile marshes and estuarine forests for pasturage and agriculture. The coastal malaria vector Anopheles atroparvus found hibernation chances in human settlements, stagnant brackish water provided sites for breeding in oxbow lakes and health risks increased in embanked polders with high-days from 1500-1750 AC [14].

Severe storm surges damaged dikes during that time. This lead to dike reinforcement along the Elbe estuary whereas pollard willows were planted along the dike for protection against surge and ice-scour (Figure 3). The willow plantations led to sediment accretion and prepared the foreland for the use as meadows and pastures. In addition, willow rods were harvested, used for fascines and groynes, and since 1800 until 1950 an extended willow culture for basketry, furniture is reported for most of the Haseldorfer Marsch [15], one of Europe`s largest tidal freshwater wetlands. However, after a major flood in 1962 a new constructed dikeline lead to the loss of approximately $75 \%$ of the former TFW area in the Haseldorfer Marsch. De Biesbosch 
consisted of approximately 8,000 ha TFW but lost vast areas due to the construction of a storm surge barrier. However, still more than 1.500 ha TFW exist including bulrush (Bies = Dutch word for bulrush; Bosch = bush) at lower and willow forests and coppices at higher elevations [11]. Bulrush and willows enhance sediment deposition and floodplain landform construction controlling ecosystem changes in space and in time [2]. Thus, creation of vegetated tidal wetlands in suitable locations for ecosystem-based coastal defence is recently proposed as an economic and ecologic supplement to conventional engineering [16].

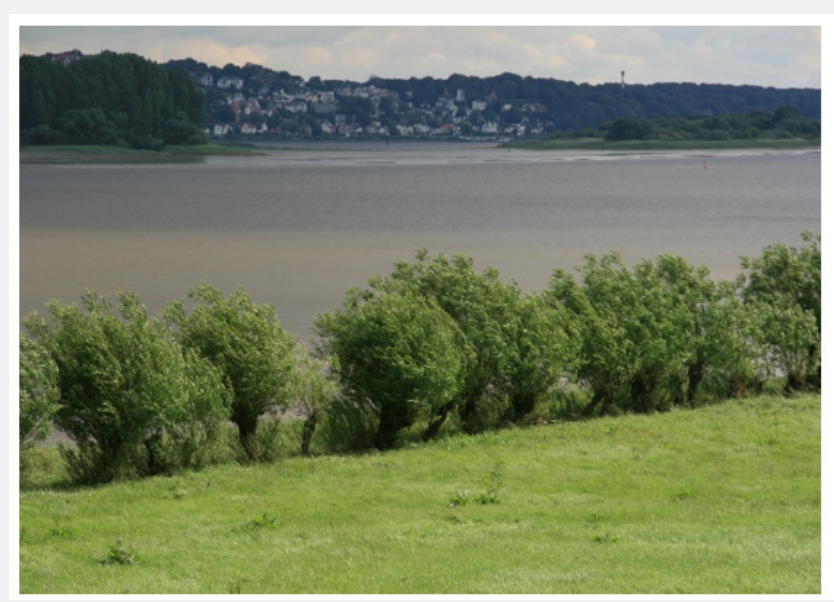

Figure 3: Planted Pollard Willows in front of the dike in the Elbe Estuary, GER.

These findings suggest that the floodplain willow is not only key resource and develops floor for life but evolves valuable and characteristic traits due to human cultivation what leads to the call "Make me a willow cabin at your gate" to implement tidal willow forest plantation and restoration [3].

\section{Acknowledgement}

The author likes to thank the colleagues at Royal Netherlands Institute for Sea Research Yerseke, NL, for fruitful discussion on the topic and Matthias Michalczyk, Friedrich-Wilhelm University Bonn, Department of Geography, for valuable comments that helped to improve the manuscript. We further thank the editors for the invitation to contribute to the journal.

I further wish to thank my colleagues in the Department Wetland Sciences and Engineering at University of Maryland for inviting me as a guest scientist to study the Chesapeake Bay tidal wetlands and the Genus Salix in Maryland and Washington DC.

\section{References}

1. Karrenberg S, Edwards PJ, Kollmann J (2002) The life history of Salicaceae living in the active zone of floodplains. Freshw Biol 47: 733748.

2. Corenblit D, Steiger J, Gurnell AM, Tabacchi E, Roques L (2009) Control of sediment dynamics by vegetation as a key function driving biogeomorphic succession within fluvial corridors. Earth Surf Process Landf 34: 1790-1810.

3. Markus-Michalczyk H, Michalczyk C (2018) Make me a willow cabin at your gate: Legislation and implementation of tidal forest restoration at estuarine upstream sites. Estuarine Coastal Shelf Sci 210: 1-6.

4. FAO (2014) Poplars and willows: Trees for society and the environment. Isebrands JG, Richardson J (Eds.), CABI and Food and Agriculture Organization of the United Nations (FAO), Rome, Italy.
5. Kuzovkina YA, Weih M, Romero MA, Charles J, Hurst S, et al. (2008) Salix: botany and global horticulture. Horticultural Reviews 34: 447489.

6. Skvortsov AK (1999) Willows of Russia and Adjacent Countries: Taxonomical and Geographical Revision (translated from: Skvortsov AK (1968) Willows of the USSR. Taxonomic and Geographic Revision. Nauka, Moscow) Joensuu University, Finland.

7. Dickmann DI, Kuzovkina YA (2014) Poplars and Willows of the World. In: Isebrands JG, Richardson J (Eds.), Poplars and willows: Trees for society and the environment. CABI and (FAO), Rome, Italy.

8. Kandus P, Malvarez AI (2004) Vegetation patterns and change analysis in the lower delta islands of the Parana river (Argentina). Wetlands 24: 620-632.

9. Baldwin AH, Barendregt A, Whigham DF (2009) Tidal freshwater wetlands, an introduction to the ecosystem. In: Barendregt, A, Whigham DF, Baldwin AH (eds), Tidal freshwater Wetlands. Backhuys Publishers Leiden, Netherlands, p. 1-10.

10. Jones MC, Bernhardt CE, Krauss KW, Noe GB (2017) The impact of late Holocene land use change, climate variability, and sea level rise on carbon storage in tidal freshwater wetlands on the southeastern United States coastal plain. J Geophys Res Biogeosci 122: 3126-3141.

11. Struyf E, Jacobs S, Meire P, Jensen K, Barendregt A, et al. (2009) Plant Communities of European Tidal Freshwater Wetlands. In: Barendregt, A, Whigham DF, Baldwin AH (eds), Tidal freshwater Wetlands. Backhuys Publishers Leiden, Netherlands, p. 59-70.

12. Kuzovkina YA, Quigley MF (2005) Willows Beyond Wetlands: Uses of Salix L. Species for Environmental Projects. Water Air Soil Pollut 162: 183-204.

13. Stone E (1763) An Account of the Success of the Bark of the Willow in the Cure Agues. In a Letter to the Right Honourable George Earl of Macclesfield, President of R. S. from the Rev. Mr, Edmund Stone of Chipping Norton Oxfordshire. Philosophical Tranactions 53: 195-200.

14. Knottnerus $O$ (2002) Malaria Around the North Sea: A Survey. In: Wefer G, Berger W, Behrke K-E, Jansen E (Eds.), Climate Development 
and History around the North Atlantic Realm. Springer-Verlag Berlin Heidelberg, Germany, pp. 339-353.

15. Adler E (1933) Die Aufzucht von Korb- und Bandweiden ihre volkswirtschaftliche Bedeutung und handelspolitische Förderung ihre Kulturtechnik und Rentabilität. Hendorns Buchdruckerei, Uetersen, Germany, pp. 28-66.
16. Temmerman S, Meire P, Bouma TJ, Herman PMJ, Ysebaert T, et al. (2013) Ecosystem-based coastal defense in the face of global change. Nature 504(7478): 79-83.

\section{Your next submission with Juniper Publishers will reach you the below assets}

- Quality Editorial service

- Swift Peer Review

- Reprints availability

- E-prints Service

- Manuscript Podcast for convenient understanding

- Global attainment for your research

- Manuscript accessibility in different formats

( Pdf, E-pub, Full Text, Audio)

- Unceasing customer service

Track the below URL for one-step submission https://juniperpublishers.com/online-submission.php 